\title{
A study of mortars prepared with fly ash and silica fume for use in structures exposed to marine enviroments
}

\author{
Y. Hernández", O. de Rincón* and R. Fernández*
}

\begin{abstract}
The purpose of this study is to evaluate different mortar mixtures containing 5,10 and $15 \% \mathrm{P} / \mathrm{P}$ silica fume and $5,10,12.5,15$ and $17.5 \% \mathrm{P} / \mathrm{P}$ fly ash to be used for repairing/constructing reinforced concrete structures exposed to marine environments. These were evaluated from the following standpoints: physical-chemical (capillary absorption and effective porosity); mechanical (compressive strength); electrochemical (lineal polarization, cyclic polarizacion and rapid chloride permeation); morphological (scanning electron microscopy). Results showed that $15 \%$ silica fume mixture whith no fly ash gave the best performance from both the physical-mechanical as well as the economic standpoint.
\end{abstract}

Keywords $\quad$ Reinforced concrete corrosion. Special mixtures. Silica fume. Fly ash. Rapid chloride permeation. Mortar morphology.

\section{Estudio de morteros con microsílica y ceniza volante para estructuras expuestas a ambientes marinos}

Resumen

El presente trabajo tiene como finalidad evaluar diferentes mezclas de mortero con contenidos de 5,10 y $15 \% \mathrm{P} / \mathrm{P}$ de microsílica y contenidos de $5,10,12,5,15$ y $17,5 \% \mathrm{P} / \mathrm{P}$ de ceniza volante para ser utilizadas en la reparación/construcción de estructuras de concreto armado expuestas a ambientes marinos. Se evaluaron desde el punto de vista físico-químico (absorción capilar y porosidad efectiva), mecánico (resistencia a la compresión), electroquímico (polarización lineal, polarización cíclica y permeabilidad rápida de cloruros) y su morfología por medio de microscopía electrónica de barrido. Los resultados permitieron seleccionar la mezcla conteniendo $15 \%$ de microsílica sin ceniza volante, tanto desde el punto de vista físico-mecánico y electroquímico como económico.

Palabras clave Corrosión en concreto armado. Mezclas especiales. Microsílica. Ceniza volante. Permeabilidad rápida de cloruros. Morfología de morteros.

\section{INTRODUCTION}

A steel reinforcement embedded in concrete with an adequate proportion of cement and water/cement ratio may remain unaltered for long periods of time $^{[1]}$ because of the alkaline characteristic of concrete and its semi-insulating action as a physical barrier that prevents direct contact with the environment. The porosity of a given concrete and the aggressive medium surrounding some structures may provoke corrosion of the reinforcement, with this corrosion even becoming the limiting factor for the useful life of a structure. Different types of concrete have therefore been developed with additives that improve both its physical and mechanical properties ${ }^{[2]}$. Silica fume can block pores either by itself (because of its average $0.1 \mathrm{~mm}$ particle size); or it can react with dissolved calcium hydroxide liberated by cement hydration, forming a stable hydrated calcium silicate (gel), which subsequently reduces and refines the capillary-pore system. The addition of silica fume to concrete significantly reduces its permeability and increases its compressive strength. Fly ash increases the workability of the material in its plastic state due to an increase in the particle dispersal in the system, creating smaller units and, consequently, greater fluidity ${ }^{[3]}$.

${ }^{*}$ ) Centro de Estudios de Corrosión. Facultad de Ingeniería. Universidad del Zulia. Maracaibo, Venezuela. Apdo. 10482. 
In conclusion, adding silica fume and fly ash to concrete enhances its physico-mechanical properties, which would allow the use of this type of concrete in aggressive environments. The use of silica fume has begun in Venezuela, but fly ash has not, because Venezuelan fly ash does not meet the standards because of its high vanadium content and high porosity, which causes great consumption of water in the mixture ${ }^{[4]}$. Besides, given the specific characteristics of the aggregates available in Venezuela, it is unwise to use the mixture designs currently used in other countries. These aggregates do not meet internationally established standards. The main objective of this paper is to evaluate mortar mixes with different contents of silica fume $(5 \%, 10 \%$ and $15 \%)$ and fly ash $(0.5 \%, 10 \%, 12.5 \%, 15 \%$ and $17.5 \%)$ as a possible superplastifier substitute and then, in accordance with its physical, mechanical and electrochemical properties, select the mixture that would provide high compressive strength, low capillary absorption, low chloride-ion permeability and low corrosion rates in a marine environment, also taking the economic factor into account.

\section{EXPERIMENTAL PROCEDURE}

\subsection{Characterization of materials}

Type I Portland Cement, river sand ${ }^{[5]}$ and potable water were used for the mortar mixes. The chloride content in potable water is less than $80 \mathrm{ppm}$. Tests in line with the Joint Reinforced Concrete Committee (CCCA $)^{(6-8)}$ standards were run on the fine aggregate.

\subsection{Preparing the mortar probes}

Concrete mixture proportions were assigned using the method prescribed in "Designing Concrete Mixtures" ${ }^{\text {"[9] }}$. The mixture was designed for a compressive strength of $400 \mathrm{~kg} / \mathrm{cm}^{2}$ with w/c ratio at 0.58 . Silica fume was added at 5,10 and $15 \%$, with fly ash at $5,10,12.5,15$ and $17.5 \%$. In some cases, a superplastifier was used to maintain constant workability of all mixtures at $100 \%$. The following probes were prepared: cylindrical $\left(3^{\prime \prime} \times 6^{\prime \prime}\right)$ for electrochemical tests, cubic $\left(2^{\prime \prime} \times 2^{\prime \prime} \times 2^{\prime \prime}\right)$ for compressive strength tests, discs $(150 \mathrm{~mm} \varnothing \times 30 \mathrm{~mm}$ thick) for capillary absorption tests and discs $(100 \mathrm{~mm} \varnothing \times 30 \mathrm{~mm}$ thick) for rapid chloride ion permeability tests, all corresponding to 19 mixture designs.

Three electrodes were placed inside the electrochemical probes when the concrete was cast. Graphite was used for the reference and auxiliary electrodes $(8 \mathrm{~mm} \varnothing)$. The working electrodes ( $10 \mathrm{~cm}$ long) were made from $3 / 8^{\prime \prime} \varnothing$ steel rebars. Of these, only $6 \mathrm{~cm}$ were bare ${ }^{[5 \text { and 10] }}$. Probes were identified as follows: E.g. M.5.0.1 = Mortar with $5 \%$ silica fume, $0 \%$ fly ash, probe $\# 1$. Before the probes were made, the expansion percentage was determined in order to verify the workability of the mixture, in accordance with Standard CCCA CON 29-75 ${ }^{[11]}$.

\subsection{Evaluating the properties of the hardened mortar}

These tests were run after 28 days of curing. Among them, Compressive Strength using Standard CCCA CE 2-72 ${ }^{[12]}$. Six $2^{\prime \prime} \times 2^{\prime \prime} \times 2^{\prime \prime}$ probes were used and then mean compressive strength was determined by applying statistical principles to concrete-quality control using Standard ACI-214-65 [13]. Capillary absorption was also determined using Fagerlund's Swedish standard $^{[14]}$ as well as Rapid Chloride Ion Permeability with Standard ASTM C $1202^{[15]}$. Additionally, the Scan Electron Microscope was used to determine the porosity area of the probe, using an image-analysis procedure developed in the Corrosion Studies Center to evaluate pitting in aluminum plates ${ }^{[16]}$.

\subsection{Electrochemical evaluation}

This evaluation was carried out with the cylindrical $3^{\prime \prime} \times 6$ " probes. The different evaluation techniques used were: Periodic potential evaluation, polarization resistance and cyclic polarization tests. These were run before exposing the probes to the aggressive medium and after some registered a change in the measurements indicated above.

The potentials measurements were made using a saturated $\mathrm{Cu} / \mathrm{CuSO}$ electrode, as stipulated by Standard ASTM C (876-80) ${ }^{[17]}$. Polarization resistance was at a scan rate of $0.28 \mathrm{mV} / \mathrm{s}$. This test was run on the probes before placing them in the salt chamber, after three months' exposure in the salt chamber and after six months' exposure. Mixture performance was also evaluated by cyclic polarization curves at a scan rate of $0.28 \mathrm{mV} / \mathrm{s}$, 
before and after being exposed to the saline medium of the salt chamber.

Chloride-ion diffusion ${ }^{[5]}$ was evaluated for probes containing $10 \%$ silica fume- $0 \%$ fly ash, $10 \%$ silica fume- $-10 \%$ fly ash, $15 \%$ silica fume- $0 \%$ fly ash and the probe with no additive, using Standard ASTM C-1152 ${ }^{[18]}$.

\section{RESULTS AND DISCUSSION}

The granulometric test reported the fineness limit at 2.67, which is within the limits established for Portland cement concrete (2.3 and 3.1). As can be seen in table I, silica fume and fly ash additives comply with Standards established for the use of this type of additive in concrete/mortar. In the evaluation - fly ash vs. silica fume particles- the results showed that fly ash particles are very porous, while the silica fume are compact.

\subsection{Physical tests}

Capillary absorption was evaluated 180 days after the mixture was prepared. Results are presented in figure 1 . The probe with no additives shows the highest value in $\mathrm{m} / \mathrm{s}^{0.5}$. In accordance with the criteria established in the Fagerlund standard ${ }^{[14]}$, $\mathrm{S}<5 \cdot 10^{-5} \mathrm{~m} / \mathrm{s}^{0.5}$ is recommended for a $30 \mathrm{~mm}$ thickness. It can be seen that for 5, 10 and $15 \%$ silica fume mixtures good values are obtained with the different fly ash content. When fly ash content is $10 \%$ or greater, there is very little difference among them, regardless of silica fume content. There is quite a lot of difference between the silica fume probes and the blank probe. Considering these results and the superplastifier added to the mixture to improve workability, a durable mixture design with $10 \%$ silica fume and $<10 \%$ fly ash content or a mixture with $15 \%$ silica fume with

Table I. Chemical analysis of additives used

Tabla I. Análisis químico de los aditivos utilizados

\begin{tabular}{ccc}
\hline Compounds & Fly ash & Silica fume \\
\hline $\mathrm{SiO}_{2}$ & $58.0 \pm 1.0$ & $84.5 \pm 0.5$ \\
$\mathrm{Al}_{2} \mathrm{O}_{3}$ & $27.7 \pm 0.3$ & $0.77 \pm 0.02$ \\
$\mathrm{CaO}$ & $0.78 \pm 0.01$ & $1.43 \pm 0.01$ \\
$\mathrm{MgO}$ & $0.78 \pm 0.01$ & $8.0 \pm 0.2$ \\
$\mathrm{Fe}_{2} \mathrm{O}_{3}$ & $4.0 \pm 0.1$ & $3.1 \pm 0.1$ \\
$\mathrm{Na}_{2} \mathrm{O}$ & $0.32 \pm 0.02$ & - \\
$\mathrm{SO}_{3}$ & $0.338 \pm 0.003$ & - \\
$\mathrm{C}$ & $3.40 \pm 0.01$ & $1.54 \pm 0.03$ \\
\hline
\end{tabular}

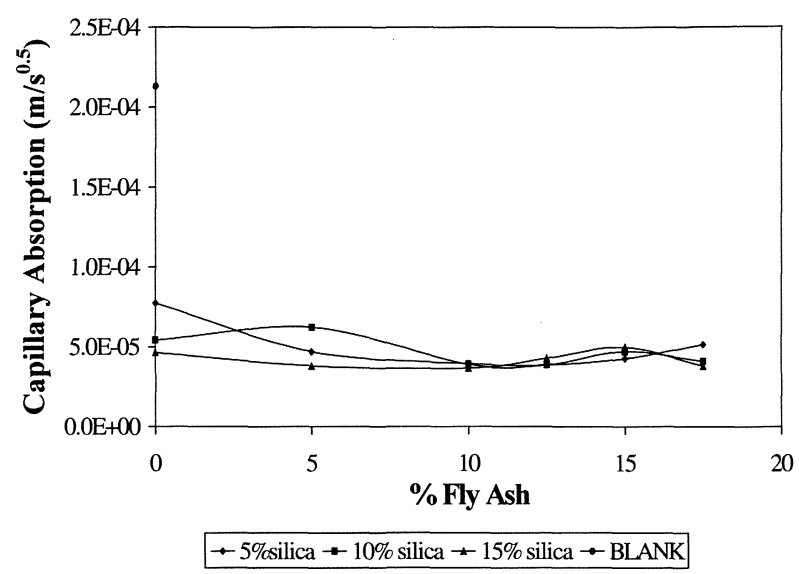

Figure 1. Capillary absorption vs. \% fly ash with different silica fume content.

Figura 1. Absorción capilar vs. \% ceniza volante con diferentes contenidos de microsílica.

any amount of fly ash or even without it, because effective porosity and capillary absorption are reduced. Taking the economic factor into account, it was observed that for the $15 \%$ silica fume mixtures a greater amount of superplastifier was used, except for the mixture with no fly ash ${ }^{[5]}$.

\subsection{Mechanical tests}

Figure 2 shows the results obtained from the Compressive Strength tests. The tests show greater Compressive Strength in the $10 \%$ silica fume probes, with the $15 \%$ silica fume curve following a similar behavior pattern. Compressive Strength values for $5 \%$ silica fume are lower than those of the probe with no additives. This shows that the Compressive Strength value is also an important

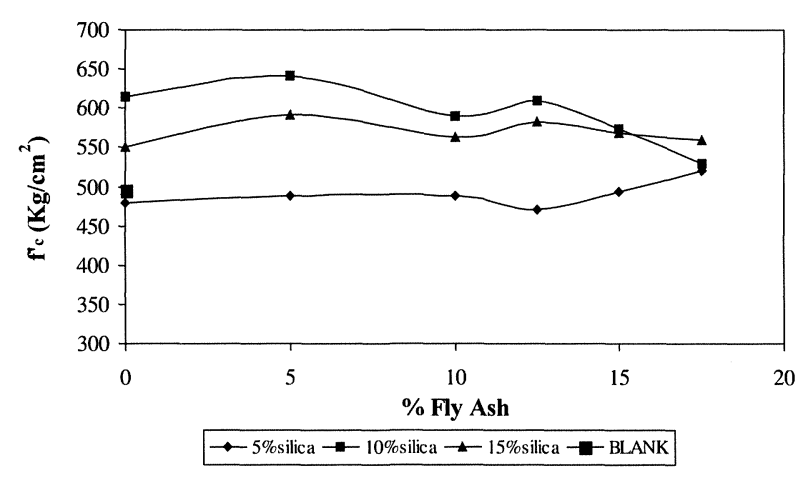

Figure 2. Compressive strength vs. \% of fly ash with different silica fume content.

Figura 2. Resistencia a la compresión vs. \% ceniza volante con diferentes contenidos de microsílica. 
variable to bear in mind when selecting the optimum mixture. Figure 2 shows that the Compressive Strength values for mixtures with $10 \%$ and $15 \%$ silica fume and fly ash between $10 \%$ and $15 \%$ are similar, and that Compressive Strength values for other fly ash content are far above those of the blank probe.

On the basis of the results obtained this far, it was determined that the mixtures with the best performance were 10.10 (10\% silica fume-10\% fly ash) and 15.0 (15\% silica fume with no fly ash), so these probes were selected for the physical tests that follow.

Figure 3 shows the Chloride Profile for each probe. In the four probes under analysis, it can be seen that the outermost area of the mortar there are concentrations greater than $4000 \mathrm{ppm}$ (allowed limit value $)^{[19]}$. The probe with no additives shows that chloride concentration in the outermost area of the disk is less than in the other probes, but that chloride content increases as it goes through the concrete, with concentration in the innermost area being higher than that of the other probes, thus indicating great ease of chloride diffusion.

A drastic reduction in chloride concentration is produced in the innermost area of the probe with $10 \%$ silica fume. The other two curves show a better performance because, in spite of there being a greater chloride concentration in the outermost area than in the probe with no additives, there is a notorious reduction in $\mathrm{Cl}^{-} \mathrm{ppm}$, thus indicating that both the $10 \%$ silica fume- $10 \%$ fly ash and the $15 \%$ silica fume- $0 \%$ fly ash are more compact, thus impeding easy chloride diffusion.

Figure 4 shows the current vs. time curve of the probes selected as optimum with their respective blanks. The sudden change in the existing charge

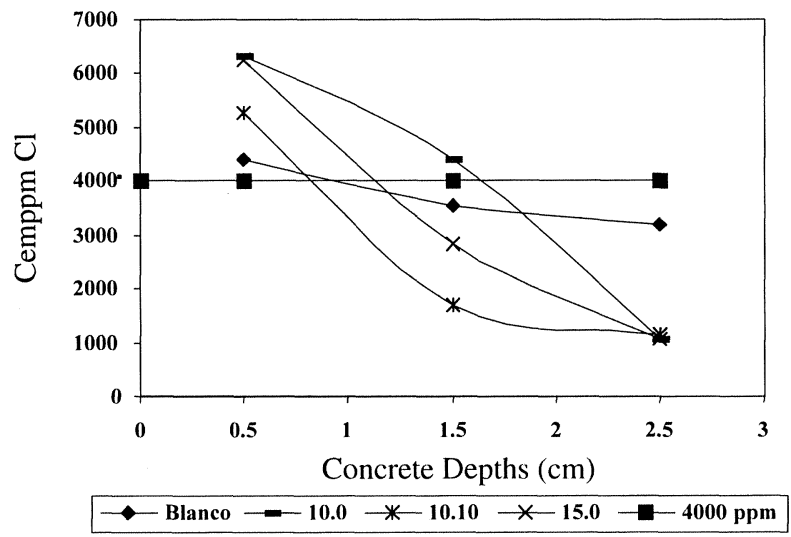

Figure 3. Chloride diffusion at different depths.

Figura 3. Difusión de cloruros a diferentes profundidades.

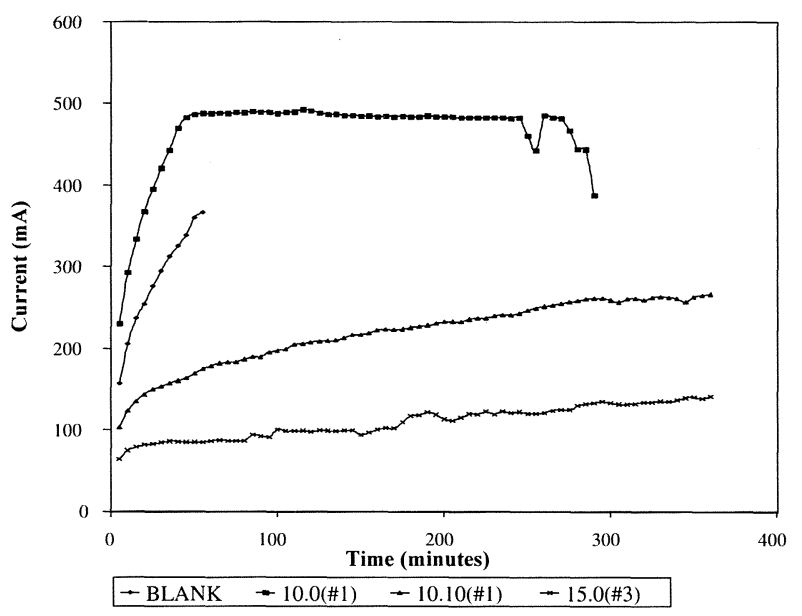

Figure 4. Comparison of rapid chloride-ion permeability in different concrete mixtures.

Figura 4. Comparación de la permeabilidad rápida del ión cloruro en diferentes mezclas de concreto.

in the blank samples and 10.0 (10\% silica fume with no fly ash) can clearly be seen, in comparison with the mixtures that have given the best results, i.e. probes 10.10 and 15.0.

\subsection{Electrochemical tests}

Measurement of Potentials. Figure 5 shows the potentials variation vs. $\mathrm{Cu} / \mathrm{CuSO}_{4}$ during exposure time. Initially, all probes reached very negative potentials. However, after curing, they reached the passive stage. At $640 \mathrm{~h}$, the potentials of all

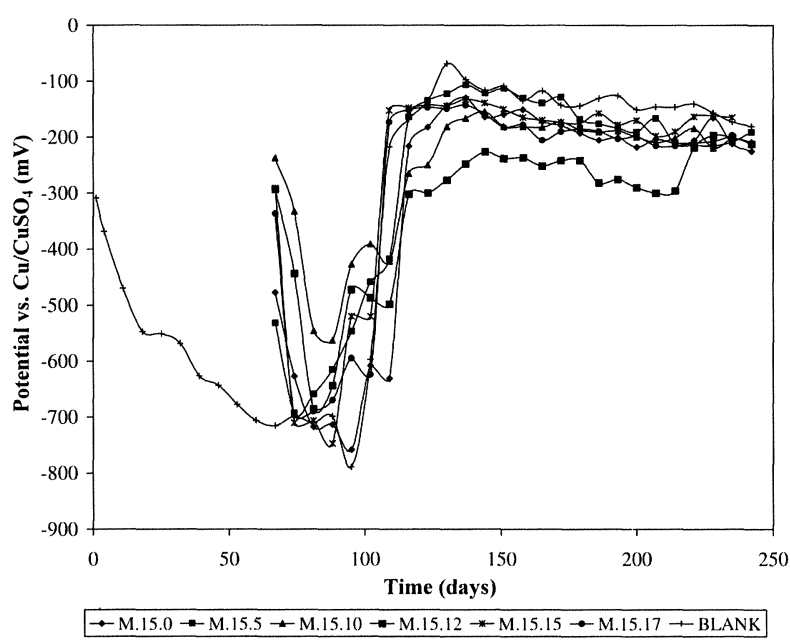

Figure 5. Potential vs. time of probes with $15 \%$ silica fume at different fly ash content.

Figura 5. Potencial vs. tiempo de probetas con $15 \%$ de microsilica a diferentes contenidos de ceniza volante. 
mixtures are in the neighborhood of $-200 \mathrm{mV}$. It is worth noting that the very negative initial potentials were due to little oxygen access to the reinforcement, so the latter had not begun passivating, thus indicating active potentials. The results to date show no variation in reinforcement performance, since the aggressive medium has not reached it in quantities that would cause corrosion ( $\geq 4000 \mathrm{ppm} /$ cement).

\subsection{Polarization resistance}

The results did not show any great difference between the different mixtures under evaluation. In Cyclic Polarization, there was a superimposition of the cyclic curves of the probes before and after exposure in the salt chamber. No destruction of the passive fume was observed after the exposure time. Figure 6 shows curve behavior for the $15 \%$ silica fume-0 $\%$ fly ash mixture.

\subsection{Image analysis for average pore area}

Table II shows the results obtained by image analysis (Corel Photo-Paint) to determine average pore area in the different probes selected as optimum, with area equal to $850 \mathrm{~mm}^{2}$. Determining average pore area is important in that the porosity of the different mixtures can be more accurately quantified, thus preventing an accelerated

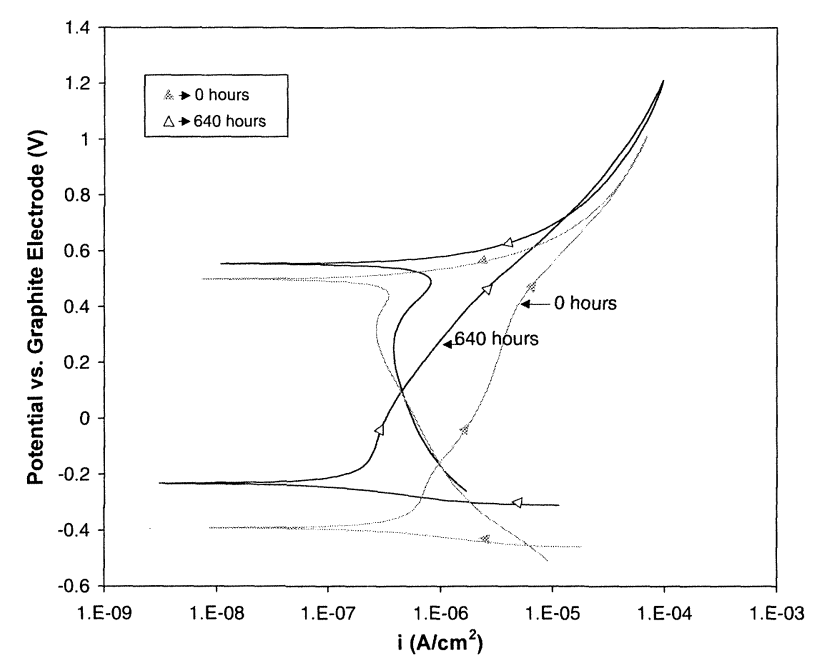

Figure 6. Cyclic polarization curve for the $15 \%$ silica fume$0 \%$ fly ash mixture before and after exposure to the salt chamber.

Figura 6. Curva de polarización cíclica para la mezcla de $15 \%$ microsilica-0\% ceniza volante antes y después de exposición en cámara salina.
Table II. Porosity area in the mortar probes with area equal to $850 \mathrm{~mm}^{2}$

Tabla II. Área de porosidad en las probetas de mortero con área igual a $850 \mathrm{~mm}^{2}$

\begin{tabular}{lcc}
\hline \multirow{2}{*}{ Probe } & \multicolumn{2}{c}{ Porosity area } \\
\cline { 2 - 3 } & $\mu \mathbf{m}^{2}$ & $\mathbf{m m}^{2}$ \\
\hline Blank & 13870 & 0.138 \\
10.0 & 93030 & 0.092 \\
10.10 & 50411 & 0.050 \\
15.0 & 31255 & 0.031 \\
\hline
\end{tabular}

corrosion process for the reinforcement when the structure is exposed to aggressive environments.

Table II shows that the porosity area in the $850 \mathrm{~mm}^{2}$ probes is progressively reduced as mortar quality improves. A pore area of $0.138 \mathrm{~mm}^{2}$ was determined for the blank probe. Pore area for the $10 \%$ silica fume with no fly ash was less than the blank probe $\left(0.092 \mathrm{~mm}^{2}\right)$ due to the silica fume. The pore area in the probe with $10 \%$ silica fume and $10 \%$ fly ash is even smaller, with a value of $0.050 \mathrm{~mm}^{2}$. The probe with the smallest porosity value $\left(0.031 \mathrm{~mm}^{2}\right)$ is the one with $15 \%$ silica fume and no fly ash.

\section{CONCLUSIONS}

- An analysis of the physico-mechanical tests (compressive strength, capillary absorption, chloride diffusion and rapid chloride-ion permeability) shows that the use of silica fume improves mixture properties in comparison with the probe with no additives.

- Adding fly ash does not improve the abovementioned properties in the mortar with silica fume.

- It must be pointed out that the mixture with $10 \%$ silica fume does not produce the expected results. It has the greatest strength among the different designs, but also the highest capillary absorption and rapid chloride-ion permeability, which indicates that the tests must be repeated in order to evaluate the design once more.

- The mixture with silica fume at $15 \%$ produced the best results.

- From the electrochemical point of view, the results do not show any significant changes, which shows that the exposure time in the saline medium $(640 \mathrm{~h})$ has not been enough to depassivate the reinforcement. 
A study of mortars prepared with fly ash and silica fume for use in structures exposed to marine environments

Y. HERNÁNDEZ, O. DE RINCÓN AND R. FERNÁNDEZ

\section{REFERENCES}

[1] M.C. AlOnSO and M.P. LuxÁN, Aplicaciones de las Cenizas Volantes en el Campo de la Construcción. Experiencia Española, Instituto de Ciencias de la Construcción Eduardo Torroja, Madrid (España), 1995.

[2] B. BRESLER, Concreto Reforzado en Ingeniería, Vol. I. Editorial Limusa, México, 1981.

[3] Z. BAYASI, Concr. Int. 144 (1992) 52-54.

[4] J. BRavo and E. Seijas, Trabajo Especial de Grado, Facultad de Ingeniería, LUZ, 1994.

[5] L. HeRnÁNDEZ and E. Yolanda, Trabajo Especial de Postgrado, Maestría en Corrosión, Postgrado de Ingeniería. LUZ, 1999.

[6] NORMa COVEnIn 0255-77, 1977.

[7] Norma COVENIN 0263-78, 1978.

[8] NORMA COVENIN 0268-78, 1978.
[9] R. FernándeZ, Proyecto CONDES 257-81, Venezuela, 1981.

[10] O. García, Trabajo de Ascenso en proceso.

[11] Norma COVEnin 1610-80, 1980.

[12] ASTM C 109-90, 1990.

[13] American Concrete Institute. Standard ACI 214-65, 1965.

[14] The Nordic Concrete Federation, Concrete Association of Denmark, Olso, Diciembre, 1982.

[15] ASTM C1202-97, 1997.

[16] T. Ríos and L. Moros, Trabajo Especial de Grado, Facultad de Ingeniería, LUZ, 1999.

[17] ASTM C 876-91, 1991.

[18] ASTM C 1152-90, 1990.

[19] O. T. DE Rincón, A. ROMERo et al., DURAR, CYTED, 1997. 